\title{
Ethnic Conflict between the Muslims and Christians in Nigeria: The Dilemma of Decision-Making of the Political Elites
}

\author{
Ray Ikechukwu Jacob
}

E-mail: rayjek.kita.ukm@gmail.com

\begin{abstract}
This paper examines how ethnic conflict occurred as a result of actions or decisions made by either local government, state or federal government in Nigeria. Ethnic conflict can be triggered due to various factors, such geographical proximity, group identity, deliberate manipulation of negative perceptions by political leaders, competition of resources, weakness of political institution transitions to democracy, and etc. However, the main focus of this paper is the implementation of Shari'a law in the Northern Nigeria and how the decisions and the implementations have led to blood-shed conflicts in the country. In general, a number of blood-shed events that occurred in Nigeria are also due to the process of decision-making by the political elites that could not fulfil the requirements of the respective ethnic groups. The implications had been overwhelmingly devastating in the country. Uncountable lives were lost via mayhem and bloodshed wars. Homes, shops and properties were destroyed. The economic implications of ethnic conflict have resulted in unequal distribution of resources among individual, groups and regions within the country. The growing economic disparities may increase the fear of those ethnic groups that are disadvantaged; this has warranted that the ignorant masses are often being remote and mobilized by the political class to engage in religious crisis in order to achieve their selfish political interests. In the same vein, similar ethnic based political movements have arisen in Nigeria. Therefore, decision-making is one source that could lead to ethnic conflict in a multi-cultural and ethnic country like Nigeria. Decisionmaking approach was used to examine the scene of conflict by focusing only on the religious conflict between Muslims and Christians in the country.
\end{abstract}

Keywords: Decision-Making, Ethnic Conflict, Religious Conflict, Government, Shari’a law.

\section{Introduction}

Nigeria is one of the most ethnically complex countries in the world, with more than 200 ethnic groups with population, more than 131 million. The country is potentially one of Africa's richest states. However, ethnic problem together with years of military rule and "rampant" corruption, have kept the majority of Nigerians impoverished. Ethnic problems in Nigeria are closely linked with other divisions in the country. The three main ethnic groups are the Hausa-Fulani (21 percent), the Ibo (18 percent) and the Yoruba (11 percent). These ethnic groups dominate different parts of the country, creating both regional and ethnic divides. The Hausa and the Fulani are north-ward, the Yoruba are concentrated in the west, 
and the Ibo live in the east. Each ethnic group has its own dominant language and culture but the most complicating ethnicity in Nigeria is religion. The northern part of the country is dominated by Muslims while the southern and eastern regions are populated mainly by Christians.

Besides, economics has been at the heart of the nation's ethnic struggles. The country's petroleum wealth is located in the Ibo region, the southeast. Politically and militarily divided, this country is deep in ethnic conflict. The northerners, primarily the Hausas, have ruled the country for most of its history. They have controlled the military regimes and the leadership seats of the nation. The Yoruba blamed the northerners for the country's political and economic problem and have led the pro-democracy movement against military rule. The discovery of petroleum in the Ibo region heightened competition among the regions. The Ibo believed that the independence of their region would protect their interest. In 1966, the Ibo region declared its independence for the state of Biafra. After three years of warfare, more than a million people died. The brutality of the Biafran war and the domination of the country's resources and politics by military regimes from the north continue to influence ethnic relations in Nigeria (Payne \& Nassar 258-259).

In July 1998, the military leader released a plan to return power to civilian rule after three decade since independence in 1960 and to move the nation on a path of political and economic reform. On 29 May, 1998 was set as the date for swearing in a new civilian president (Payne \& Nassar 1998:221). However, in 2000, ethnic violence erupted as a result of the imposed of shari'a or Islamic law on Christians living in the northern part of the country. Between 2000 and 2007, more than 54,000 people were killed in conflict between Muslims and Christians.

The main focus of this paper is the implementation of Shari'a law in Nigeria and how the decision has led to blood-shed conflicts in the country. In general, a number of such events that occurred in Nigeria were also due to the process of decision-making by the government that could not meet the requirements of the respective ethnic groups. Therefore, decision- making is one of the vital attributes that could cause ethnic conflict in any multiracial country such as Nigeria. Decision-making approach in Nigeria is analysed to further examine the scene of conflict by focusing only on the religious conflicts between Muslims and Christians in the country.

\section{Review of Past Research Related to Ethnic Conflicts}

There have been many writings by various scholars who viewed ethnicity as a cause of many conflicts in Nigeria. Handelman (2000) stated that inter-tribal conflict has a number of occasions, sparked great violence in Africa. Countries such as Nigeria, Ethiopia, Rwanda, Burundi, Uganda, Sudan and Zaire have been torn apart by civil wars that have been largely, ethnic based. Ethnic divisions are more important to understanding Nigerian society, when compared to social or labour divisions, because Nigerians differentiate themselves less by class or occupation than by ethnic group. This phenomenon (variously labelled ethnicity, ethno nationalism or tribalism) involves adherence or loyalty to a particular region or tribe, a sense of exclusivity and discrimination against people from other regions or tribes. The source of ethnic conflict, whether it is between major groups, or between larger groups and smaller minority groups, is not found in bigotry and prejudice. The real heart of ethnic conflict in Nigeria is that hostility was derived not from ethnic differences but from competition between different people for wealth and power. Politicians from each group seeked to obtain greater political power and economic benefits for their own people rather than seeked for a united Nigeria. In this context, what is most important for Nigerian development is the linkage between ethnic groups and political parties. Ethnic based interest groups and parties impeded political development and national unity by engendering mutual mistrust, but; the affiliation of ethnic groups with political parties' transferred ethnic conflict into nonviolent arena of political interaction. 
Regarding the discussion above, the key question is how did other multi-ethnic countries (Belgium, the Netherlands, Austria, Switzerland, Lebanon and Malaysia) manage their multi-ethnic society? Nordlinger (1972) claims that these six countries were free of conflict for long periods of time because elite leaders of protagonist groups were both dominant and politically skilful. By politically skilful, he means that they successfully implemented one or more of six conflict regulating practices: (i). a stable coalition between governing parties; (ii). The principle of proportionality; (iii). Acceptance of a mutual veto; (iv). Purposive depoliticization; (v). Mutual adjustment of conflicting values and interests through compromise and (vi). Concessions by the stronger group. When conflict regulation succeeds, "at least one of the six practices is invariably present (Nordlinger 1972: 20).

This paper explores the case of ethnic conflict in Nigeria from a different perspective. Some scholars agreed that conflict is a result of ethnicity, but they failed to realize that conflict is the result of a decision made, which the implementation of it results in commotion or violent action, and this may draw in more or less people to participate. This paper tried to picture the ever lengthening ethnic conflicts in the country with the familiar but misappropriated and misused two English words, "Fact" and "Truth". These two words seem to mean one thing, but in actuality, their meanings are not the same at all even though the words might seem dependent on one another. "Facts" about ethnicity stirring conflict, might not be the "Truth" about the same conflict that seems to have been stirred by ethnicity. "Facts" can mean "colour" or "Paint" or even as a way to "justify" the fact about a matter, which obviously, might not be the root of a particular problem. In this case, there is no doubt that a colour-blind short-sighted eyes can label every ethnic conflict to be caused by ethnicity. The word "Fact" is the immediate or present condition of a particular thing, place, person, state, etc., at the moment of time it was seen. Whereas the "Truth" is the original state of things, etc. People who confuse and misappropriate the two words, no doubt can accept that conflicts are product of ethnicity. It could be a colour, masque, painting or even justification in disguised. This paper, critically analyses why Nigeria cannot manage its conflict, compared to Belgium, the Netherlands, Austria, Switzerland, Lebanon and Malaysia. As in the case of Nigeria, some of these peaceful countries were also once colonized by the British.

In holistic perspective, the writer agrees that various ethnics in Nigeria cannot cause the conflicts recorded in Nigerian history. Rather, there must be an unidentified and hidden root (selfishness and selfinterest) which seems to be generating and intensifying fire of ethnic conflicts in Nigeria. Even the new Nigerian leaders and rulers fail to see what the colonial masters have handed over to them--the colonial construct-program is still in place, left to continue running and to achieve its goal without failing, regardless of who is leading. The program was designed to work in the favour of the ex-colonial masters (British) while, the people of Nigeria suffered. The British influenced the northern traditional rulers to implement certain policies. The westernization approach used by British reinforced the regional differences in the country (Payne \& Nassar 2008:259).

\section{Decision-making Approach in Explaining the Conflict}

Underlying every human endeavour is a decision or some decisions taken by concrete person or persons. Thus, understanding human activities would generally demand the determination of underlying decision or decisions that triggered off the activity or activities. Decision, therefore, constitutes the basic unit in the analysis of human actions.

In this paper, the conflict and political process approach introduced by Conn (1971) will be useful to explain the relationship between conflict and decision-making process. This approach is further modified to be consistent with this presentation questions about how far decision-making has caused ethnic conflict in Nigeria. Conn stated that political decision- making has been the product of autocratic rules. According to him, there are several types of variables considered by the actors before deciding whether to engage in conflict such as: 
- Goals or survival-will depend upon such simple needs as food, shelter, protection from predators, and protection of the species.

- Resources-the resources at the disposal of the individual combatant also influence his behaviour and attitude toward engaging in conflict. The attainment of a particular goal may be important to an individual but his choice of arena for the satisfaction of that goal will vary according to his resources.

- Institutions and structures-societies and government develop institutions in order to implement and regularize the desired norms of conduct. The nature of the political order is usually characterized the basic charter of constitution of a society. A constitution stipulates the institution comprising the political structure, the procedures of government, and the appropriate channels for the exercise of political power.

- Norms and mores of conduct-The norms of conduct exert an official and unofficial power in determining the type of conduct which will be pursued by persons or parties in conflict situations. Combatants are expected to adhere to these norms, and violating them often brings punishment.

- Strategies-is the particular set of tactics, moves, or behaviour which the actors adopt to achieve his goal. The type of strategy a person pursues may be varied. He may employ a single strategy or multiple strategies. He must consider whether it is an insider strategy (that is one that can be pursued within acceptable framework which the society has set up, or an outsider strategy, one that the society may regard as illegitimate). Conn (1971) discussed a process of conflict resolution within the political arena. The first two are the potential actors can operate. Conflicts naturally will arise as these individuals or groups, each with their own goals, interact. Many of these conflicts, however, do not become political in nature. They will both be unimportant and tend to fade away from or they will be worked out by the parties to the disputes through the use of non-political channels or was mentioned as political channels bypass.

Each actor mentioned above, has certain goals and demands which may clash with those of other interested parties. At first, his desires may be diffused and unarticulated, but as he sees that the conflict is important and has political ramifications, he will tend to enumerate his demand as positively and as distinctly as possible. It is here, with the generation of demands that the first phase of conflict within the political process actually begins, it is here that the participants strive for activation or politicization of their conflict. They will attempt not only to state their demands in politically attractive terms but also to formulate strategies and enter into political coalitions in hopes of winning their case. They will try to put themselves in the most advantageous position possible as they enter into the second phase of the process, political decision-making.

In decision-making process, the coalitions and alliances (or individual, where no alliances are formed) present their demands and direct them toward those institutions which are designed to handle such demands. If the coalition is successful, some form of decision will be made. The third phase is execution and integration of decisions. This phase can be the end or, in a sense, the beginning. Sometimes the decision will be executed or implemented; the new status quo will be integrated into society, and the conflict will be effectively resolved. On the other hand, attempted execution of a decision may lead to new stumbling blocks and new conflicts will emerge. In this case the entire process will begin again.

Each solution and its resulting action affect the status quo, alter relationships among people, and may itself generate new conflict. Any political decision may become the basis for further activity. Even in decision or failure to take action can change the existing environment. It encourages a mood or feeling about the responsiveness of political institutions and thereby influences the level and nature of future demands. According to Conn, there are four major categories in decision- making process. These are avoidance, tabling, acceptance and rejection. Conflict and political process by Conn (1971) only explains the relationship between conflict and decision-making process as a resolution to resolve the conflict. 
Conn however did not realize that sometimes the decisions taken by the government can lead to conflicts such as in Nigeria case. Decision-making will not only be as a method to solve the conflict, it is also a way that could lead to conflict if the decision taken became contrary to the requirements of the public. Decision making can be a form of domination or control that could lead to ethnic conflict, while the mechanism that controls this decision-making is completely dominated by those with political power (Heywood, 1994). Dahl (1963) described power as a question of who gets their way, how often they get their way, and over what issues they get their way. The attraction of this treatment of power is that, it corresponds to the common-sense belief that power is somehow about getting things done, and is therefore most clearly reflected in decisions and how they are made.

Heywood (1994) stressed that, power is a form of domination or control that forces one person to obey another. In political life, power is very commonly exercised through the acceptance and willing obedience of the public. Those in power do not merely possess the ability to enforce compliance, but are usually thought to have the rights to do so as well. This highlights the distinction between power and authority. However, what transforms power into authority is the perception that power is exercised in a manner that is rightful, justified or acceptable. Legitimacy is usually seen as the basis of stable government, being linked to the capacity of a regime to command the allegiance and support of its citizens. All governments seek legitimacy; the question is on what basis do they gain it, and what happens when their legitimacy is called into question.

Heywood describes that power can be explain in three phases. First it can involve the ability to influence the making of decisions; secondly, it is reflected in the capacity to shape the political agenda and thus prevent decisions being made; and thirdly, it may take the form of controlling people's thoughts by the manipulation of their needs and preferences. Heywood opinion supports the statement of Bachrach and Maratz (1981), who said that power is reflected in the decision making process, i.e. to the extent that a person or group consciously or unconsciously creates or reinforces barriers to the public airing of conflicts, that person or group has power. Bachrach and Maratz also emphasized non decision-making process as the second phase of power. This means that decision-making approach to power encourages attention to focus upon the active participation of groups in the process; non-decisions highlight the importance of political organization in blocking the participation of certain groups and the expression or particular opinions.

Based on the model presented by Conn (1971) and decision-making approach by the Heywood (1994), Dahl (1963) and Bachrach and Maratz (1981), an operating model has been developed to guide this paper. Figure 1 describes the application of the decision-making in the examination of ethnic conflicts in Nigeria. It will expose the fact that certain persons take certain decisions that result in the conflicts registered among the ethnic groups in the country. These groups are the people who have the power to rule, control and manipulate others. Most of the conflicts in Nigeria arise from certain decisions taken by certain persons or groups.

The northerners and non-northerners constitute two different groups and each has certain peculiar interests and goals that shape the character of their members. In the assessment of ethnic conflicts in Nigeria, the leadership or government of the day should be analysed based on the perspective examined above in Figure 1. To begin with, those that actually made the vital decisions that sparked the ethnic conflicts should be identified. In most cases, the government has gone against those directly involved in ethnic conflicts while leaving out the persons acting behind the scenes, but who actually are the instigators of the conflicts. Thus, decision-making perspectives highlight the need for a new methodology or approach by the government. The truth here is that, if those acting behind the scene and those who play the major role are apprehended, the problem of ethnic conflicts could be better curtailed. Essentially, decision-making approach raises some critical questions: Who are the instigators of ethnic conflicts in Nigeria? Are the government officials, important private citizens, or traditional rulers? Whose interests do they project or promote? Does the Nigerian context encourage ethnic conflicts? Has the government done enough in stemming the tide of ethnic conflicts in Nigeria? 


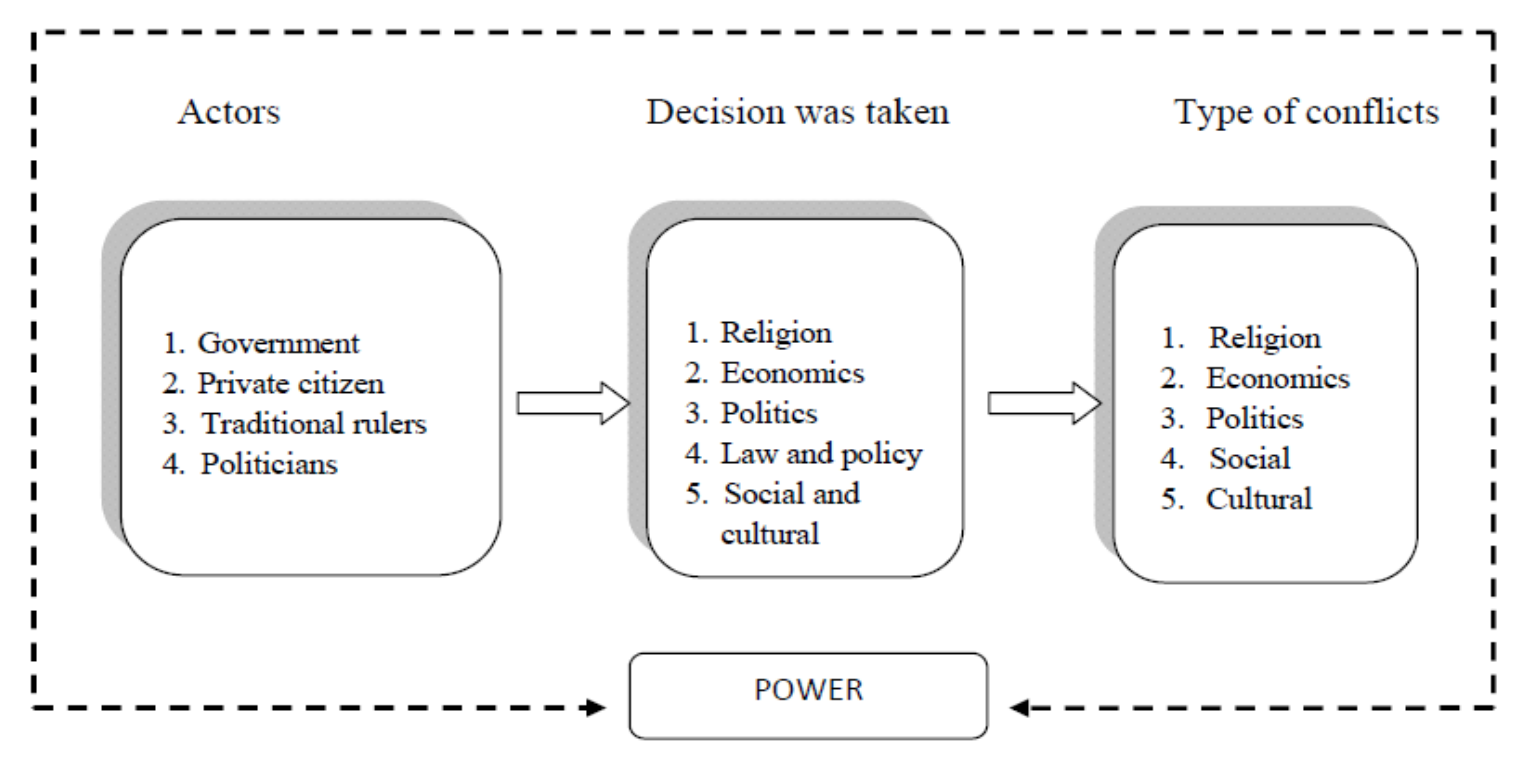

Fig. 1 Decision-making and ethnic conflict in Nigeria

\section{Religious Conflict as a Result of the Decision-Making Process}

The constitution provides for freedom of religion, including freedom to change ones religion or belief, and freedom to manifest and propagate ones religion or belief in worship, teaching, practice, and observance; however, the government restricted these rights in certain respects. The implementation of expanded version of Shari'a law in 12 northern states continued during the year. The constitution prohibits state and local governments from adopting an official; however, some Christians alleged that Islam had been adopted as the de facto state religion of several northern states that have reintroduced Shari'a criminal law and continued to use state resources to fund the construction of mosques, the teaching of Alkalis (Muslim judges), and Christian pilgrimages to Jerusalem. In general states with a Christians or Muslims majority would make Plateau state centre of Christianity. Both the federal and the state governments were involved in religious matters, including the regulation of mandatory religious instruction in the public schools, subsidies construction of churches and mosque, states sponsor participation in the hajj, and pilgrimages to Jerusalem. Muslims in some predominantly Christian states complained about religious discrimination.

Violent religious clashes broke out in the city of Kaduna in northern Nigeria on February 2000 and have continued throughout the week. Kaduna is the second largest city in the north. The clashes followed a march by tens of thousands of Christians to protest the proposal to introduce Muslim shari'a law as the criminal code throughout Kaduna state. Reports speak of rival armed gangs of Christians and Muslims roving the streets. Churches and mosques have been put to the torch. Corpses were seen lying in the streets and people's bodies hanging out of cars and buses, apparently killed while attempting to flee the violence. Local human rights workers said that more than 400 had been killed as a result of the clashes. Since the northern state of Zamfara brought in shari'a law in November 2000, it has become the focus of media attention, with a recent case in which a youth received 100 lashes for having sex before marriage, reports of the banning of women football teams and the establishment of women only taxis. Whilst the introduction of shari'a in Zamfara was peaceful, it has provoked widespread opposition in Kaduna, where unlike most northern states it has roughly equal numbers of Christians and Muslims. Shari'a has become the battle cry of vocal northern political elite, who are using the Muslim religion to advance their own 
regionalist ambitions belonging mainly to the Hausa ethnic group, they have pushed religion and ethnic issues to the force since President Obasanjo was installed as a civilian president last May 1999. Similar ethnic-based political movements have arisen in the south and west of Nigeria, with groups like the Oodua People's Congress calling for self-determination for the Yoruba, and the emergence of Ijaw, Ogoni and other movements in the Delta region. Religious and ethnic conflicts are likely to escalate as two other northern states, Niger and Sokoto have bills to enforce shari'a law that took effect in May 2000. The northern states of Kano and Yobe are expected to follow (source: http://www.wsws.org/articles/2000/feb2000/nige-f28.shtml).

The constitution states that a Shari'a court of appeal may exercise such other jurisdiction as it may be conferred upon it by the law of the state. States interpreted this language as granting them right to expand the jurisdiction of their existing Shari'a court to include criminal matters. After the adoption of Shari'a in Zamfara. Other states implemented forms of Zamfara such as Sokoto, Kebbi, Niger, Kano, Katsina, Jigawa, Yobe, Bauchi, Brono, and Gombe (See Fig. 2). Adherence to Shari'a provisions was compulsory for Muslims in some states and optional in others and enforcement varied by locale.

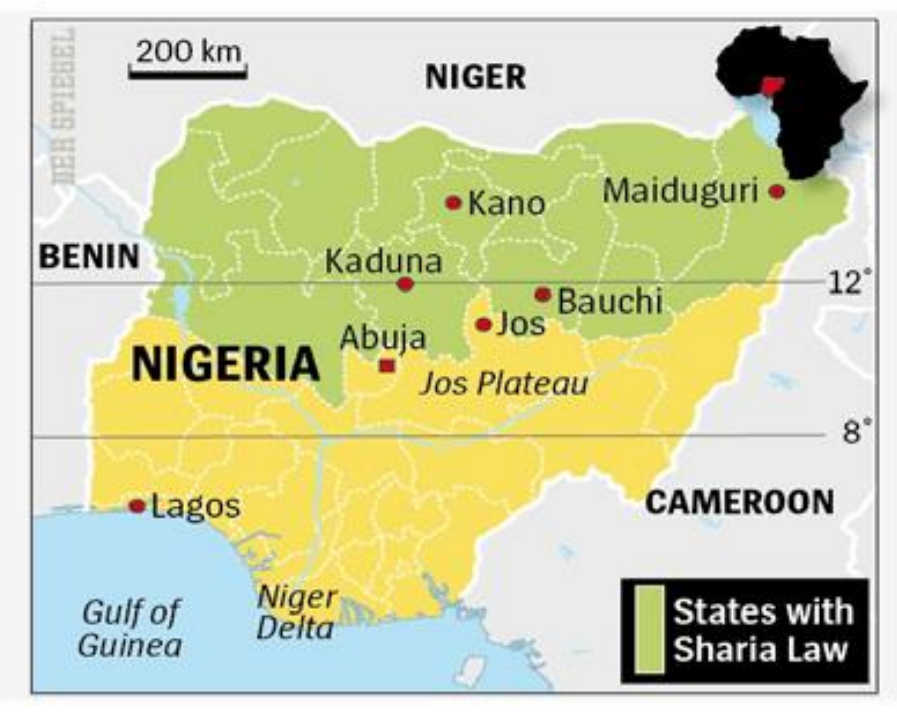

Fig. 2 Map showing states with Sharia law in the Northern region

In November 2001, Kaduna state established a modified version of Shari'a law. The criminal and procedural codes did not come into effect until July 2002, and national human right groups reported that the court in Kaduna issued several sentences for minor offenses in September. These sentences did not include corporal punishment. Christian and Islamic groups planning to build new churches or mosques were required to register with the corporate affairs commission (CAC). The CAC did not deny registration to any religious group during the year: However, some religious groups experienced delay in obtaining permission from local zoning board to build houses of worship. Many nascent churches and Islamic congregations ignored the registration requirement, and a small number had their place of worship short down because of enforcement of zoning laws. Some people claimed that enforcement of these laws was selective. In August 2005, the Christian association of Nigeria (CAN) issued a communiqué in which they criticized the destruction of churches in the north (Source: http://www.anglicannig.org/CAN_reaction.htm).

Christians in the predominantly Muslim northern states alleged that local government officials used zoning regulations to slow or stop the establishment of new churches. Officials responded that many of these new churches were being formed in residential neighbourhoods not zoned for religious 
purposes. They CAN offices in Zamfara and Sokoto states alleged that local authorities delayed or denied to Christians certificates of occupancy (COS), which were required to show title to land. Zamfara and Sokoto state officials denied that religious discrimination influenced the cases cited by CAN. State officials said the ratification boards were dealing with a large backlog of cases for all people, regardless of religious faith. Muslims complained that they were denied permission to build mosques in predominantly Christian southern of Abia, Akwa-Ibom. Although the government does not prohibit or discourage conversion from or to a particular religion, there was a media report that two men were brought to trial by Zamfara state from converting from Islam to Christianity. Persecutors sought the death penalty; However Shari'a code did not explicitly criminalize apostasy and he determines there were legal bases for the case. Nevertheless, he gave the men three days to reconsider their alleged conversion and for the Zamfara government to furnish a legal base why he should hear the case. The men were accused of joining the evangelical church; however, they claimed that they were never Muslims but were ethnic Magazawa, An Hausa sub group that has long practiced Christianity. There was no further action in this case by year end (Source: http://www.house.gov/international-relations).

Report that state and local government officials discriminated against persons practicing a religion different from their own were common, notably in hiring or awarding contracts, and private businesses frequently were quietly of informal religious and ethnic discriminating in their hiring practices and purchasing patterns. Unlike in the previous years, there were no reports that political party members were suspended because of religious belief or adherence. According to media reports on 21st July 2002, nurses in the Federal Medical Center in Azare, Bauchi state were fired for not wearing compliant dresses, and the Zamfara state government required Muslim dress for secondary students. As a result of ethnoreligious violence related to the expansion of Shari'a criminal law in 2000. Several northern states governments continued to ban public proselytizing during the year, although it is permitted by the constitution. The Katsina and Plateau state governments maintained a ban on public proselytizing for security reasons during the year; however, some groups were allowed to carry out activities despite these formal bans, which generally were enforced on a case by case basis (source: http://www.allafrica.com).

Unlike in the previous year, there were no reports that missionaries were harassed for proselytizing. Both Christian and Muslim organization alleged that the Ministry of Foreign Affairs and the Immigration Department restricted the entry into the country of certain religious practitioners, particularly persons suspected of intending to proselytize.

Proselytizing did not appear to be restricted in the southern part of the country. The government continued to enforce a ban on the existence of religious organization campuses of primary schools, although individual students retained the right to practice their religion in recognized places of worship. According to the constitution, students were not required to receive instruction relating to religion other than their own; however, public school students in parts of the country were subjected to mandatory Islamic or Christian religious instruction. State authorities claimed that students were permitted to decline to attend these classes or to request a teacher of their own religion to provide alternative instruction. However, there were no teachers of Christian religious knowledge in many northern schools. In Enugu and Edo states Muslim students could not access 'Islamic religious knowledge' in the public schools. Although distribution of religious publications generally remained unrestricted, the government periodically continued to enforce a ban on published religious advertisement. The Christians in Zamfara state reported that the state government restricted the distribution of Christian religious literature. (source: http://www.4humanrights.org/ng/International_Religious_Freedom_Report_2003.html).

The government acknowledged the legal authority of states to implement criminal Shari'a. Although expanded Shari'a law technically do not apply to non-Muslims, some non-Muslims, especially in Zamfara states, have been affected by certain social provision of the law, such as the separation of the sexes in health facilities; bands on the sale of alcohol and alcohol consumption; and decision by some entrepreneurs not to engage in certain activities due to concern for Shari'a restriction. In some states, cases involving only Muslims must be heard by a Shari'a court. Other states with sixth Shari'a law still 
permitted Muslims to choose common law courts for criminal case: however, societal pressure forced most Muslims to use the Shari'a court system. There were no challenges to the constitutionally of Shari'a during the year. A number of sates sanctioned private Shari'a enforcement groups that formed in states with expanded Shari'a law. Zamfara state vested the local vigilante group with full powers for arrest and prosecution because the state believed police were not enforcing the new Shari'a law. Jigawa state also mobilized a state wide Shari'a enforcement committee to arrest, detain, and prosecute Muslim offenders. Informal Shari'a enforcement groups may have been used for some law enforcement functions in other northern states as well. On $20^{\text {th }}$ November 2002, protesters destroy the Kaduna office of This Day newspaper after the paper published an article about the miss world pageant that many Muslim felt insulted their religion. More than 200 persons were killed and thousands fled their home seeking protection at government facilities, mainly military installations. Two Christian clerics died and several churches reportedly were burned. More than 100 persons were arrested, and investigations into then violence were on-going at year's end. Despite widespread calls from elements of society, the responsible journalists weren't jailed nor were the newspaper shut down. In December of the same year, the Zamfara state Deputy Governor pronounced a, "fatal" death sentence against Isioma Daniels, the journalist responsible for the November This Day article. Most Muslim leaders and the government strongly criticized Deputy Governor Shinkafis statement saying that the fatwah was wrong and that Shinkafi did not have the legal or religious authority to order it, (Sources): (http://www.allafrica.com/stories/200211300099.html).

Religious differences often corresponded to regional and ethnic differences. For example, the northern region was predominantly Muslim. Many southern ethnic groups were predominantly Christian, although the Yoruba were approximately 50 percent Muslim. But Muslims and Christian were found in large number in the middle belt. In many areas of the middle belt, Muslim Fulani tended to be hardest while the Muslim Hausa and most Christian ethnic groups tended more towards farming or urban living. It often was difficult to distinguish religious discrimination and tension for ethnic, religion, economic and land use competition. Often religious tensions underscored what was a predominantly ethnic and economic confrontation during the year. The middle belt experienced recurring ethno-religious violence during the year but overall violence decreased markedly from the previous year's levels. In February 2002 between 60 and 100 persons were killed when Yoruba youth clashed with Hausa residents in the Idi-Araba area in Lagos. The incident was cause by inter- ethnic tensions but had some religious overtones (The Post Express, 5 February. 2002). There also were several incidents in which Muslim youth vandalized Christian churches. For example, in June there were unconfirmed reports that Muslim youths set fire to four churches Dutse, Jigawa State (Coleman, 1958). Ethnic-religious conflict continued in many parts of Plateau during the year. There was no single incident that matched the violence and destruction of the September 2001 fighting in and around Jos; however, repeated outbreaks of violence caused dozens of death and resulted in the destruction of places of worship, shops and homes. According to local leaders and other observers, because of this violence, Muslim moved away from Langtang and Christians vacated the village by year's end. Existing tensions between Christians and Muslims caused minor incidents, such as a traffic accident, to escalate into communal violence. For example, a dispute apparently began after a Muslim man proposed marriage to a Christian woman. The woman's brother beat her, and when her fiancée intervened, a fight ensured. What began as a family dispute quickly expanded to other parts of the community, assuming ethnic and religious overtones as it spread. The Plateau state government convince in the Plateau state peace summit to address the problem of communal and religious violence in the state. An NGO that specialized in conflict resolution also was involved actively in the state. There were no developments in the 2001 and 2000 incidents of inter-relations violence.

The religious conflict above involved a number of groups; Muslims and Christians in the north. The conflict between these groups was extremely intense in 2002. Muslim-based armed groups include the Arewa People's Congress (APC), Hisbah Groups (Islamic vigilante groups that enforce adherence to Shari'a), the Zamfara State Vigilante Service (ZSVS), and Al-Sunna Wal Jamma (also known as the Taleban and Bokoharam. 
- There are numerous small Christian militias. While some of the armed groups are clearly motivated by religion, often religion is used as a cover for disputes over land and cattle that have traditionally occurred between farming communities (who are mostly Christian or practice indigenous African religions) and cattle herders (who are mostly Muslims.) This is especially true in Plateau state where the most violent episodes of religious violence have occurred.

- Sunni and Shiite Muslim communities in the northern state of Sokoto. Minority ethnic groups have exploited the religious component of these conflicts in order to further engage in farming and cattle rustling disputes in this mainly agrarian state. While both Christians (who are mainly farmers) and Muslims (primarily cattle herders) have pointed to identification cards recovered during combat as proof that their adversaries are religiously motivated, its true role is insignificant except for the fact that the various ethnic groups involved just happen to belong to one or the other. The Fulani and Wase militias are exclusively Muslim, for example, while the Taroh and Gamai militias are nonMuslim - and are made up of Christians and practitioners of African traditional religions (IRIN news.org, June 6, 2005).

- Hundreds of armed gangs, known as "cults" also contribute to violence in Nigeria. Cults may be involved in a number of activities such as organized crime especially the theft of oil, vigilante actions/community self-defense, ethnic and/or religious violence and party politics (hired by local politicians to help influence political outcomes). They are usually made up of a small number of poor youths who view the gangs as one of the few opportunities for economic gain and protection. The largest among them include the Bakassi Boys in south-eastern Nigeria and the Niger Delta Vigilante (NDV) active in Rivers state. The Niger Delta Vigilante is led by Ateke Tom, one of the most wanted men in Nigeria, and has an active membership of several hundreds. It has a small fleet of speedboats used in the transporting of stolen oil and kidnappings. The oil-producing Niger delta of south eastern Nigeria has been plagued by powerful armed gangs for several years. Some of them have been set up to fight for the interests of rival ethnic groups and several make money from crime, particularly the theft and smuggling of crude oil and kidnapping for ransom (IRIN news.org, June 21, 2005).

\section{Conclusion}

In a multi-ethnic country, any decision or legislation should take into account the sensitivity of each ethnic group. In several countries, religion may be a sensitive issue; this issue that is often used by interest groups for their political survival. As a result, if not addressed, conflicts of religion/ethnic would surface. Religious conflict broke out due to ethnic disputes that have occurred previously. Some northern states government's decision to introduce Shari'a law increased the anger among Christians, especially in the north. The implementation of Shari'a law also involved those Christians who live in the north. Decision-making approach has been able to explain the real causes of ethnic conflicts in Nigeria. This approach is able to identify the actor who is behind the conflicts, and the decisions taken by them which led to religious conflicts in Nigeria.

\section{References}

Bachrach, P., \& Baratz, M. (1981). The Two Faces Of Power, in Castles FG, Murray DJ \& Potter DC (eds). Decisions, Organizations And Society. Penguin: Harmond-sworth, pp 50-56.

Dahl, R., A. (1963). Who Governs: Democracy And Power In An American City. Yale University Press: New Haven. 
David, F., R. \& Frank L., W. (1976). The Comparative Study of Politics, Mifflin Company. Boston.

Conn, P., H. (1971). Conflict And Decision Making: An Introduction To Political Science. New York: Harper \& Row, Publishers.

Coleman, J. (1958). Nigeria: Background To Nationalism. California: University of California Press.

Berkeley \& Nordlinger, E., A. (1972). Conflict Regulation In Divided Societies, US Center For International Affairs. Harvard: Harvard University.

Handelman, H. (2000). The Challenge Third World Development. New Jersey: Prentice Hall. Heywood, A. (1994). Political Ideas And Concepts: An Introduction. London: The Macmillan Press Ltd.

Payne, R., J. \& Jamal, R. Nassar (2008), Politics And Culture In The Developing World, Pearson Longman, New York.

IRIN news.org, June 6, 2005.

IRIN news.org, June 21, 2005.

The Post Express, 5 February. 2002. http://www.wsws.org/articles/2000/feb2000/nige-f28.shtml.

http://www.4humanrights.org/ng/International_Religious_Freedom_Report_2003.html.

http://www.house.gov/international-relations.

http://www.state.gov/g/drl/rls/irf/2001.

http://www.allafrica.com/stories/200211300099.html.

http://www.allafrica.com.

http://www.anglican-nig.org/CAN_reaction.htm.

http://www.anglican-nig.org/CANreact.htm. 